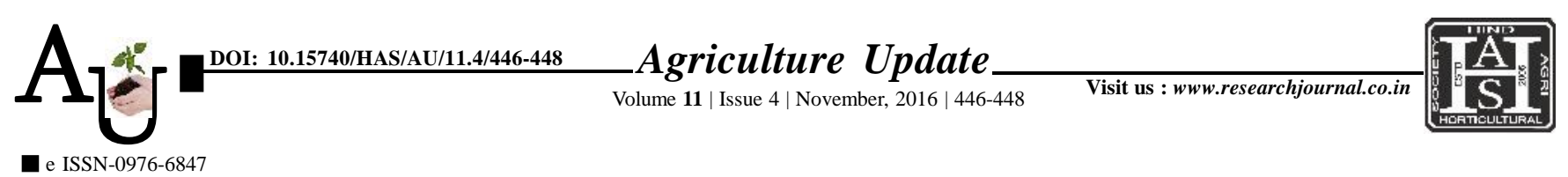

\title{
Research Article: Knowledge and adoption of recommended ratoon management practices by the sugarcane growers
}

\author{
K.V. GURAV AND R.D. NIGADE
}

Article Chronicle:

Received :

17.09.2016;

Revised :

07.10.2016;

Accepted :

23.10.2016

KeY Words :

Sugarcane growers,

Knowledge,

Adoption,

Management

practices,

Constraints

Author for correspondence :

\section{K.V. GURAV}

Zonal Agricultural

Research Station

(NARP), KOLHAPUR

(M.S.) INDIA

Email: kumargurav11

@ yahoo.in

See end of the article for

authors' affiliations

SUMMARY : The efforts were made to study the knowledge and adoption of ratoon management practices by the sugarcane cultivators from Kolhapur district of Maharashtra. The study was undertaken in purposively selected Karveer tahsil of Kolhapur district of Maharashtra in the year 2008. It is observed that most of the respondents had knowledge in respect of MPKV recommended ratoon management practices like arrangement of sugarcane trash in the furrows (100.00\%), stubble shaving $(100.00 \%)$, spraying of 0.1 per cent bavistin on stubbles $(96.00 \%)$, application of decomposing material $(86.00 \%)$ and application of $1^{\text {st }}$ dose of chemical fertilizers $(92.00 \%)$. Adoption of recommended ratoon management practices reveal that level of adoption was less as compared to their level of knowledge.

How to cite this article : Gurav, K.V. and Nigade, R.D. (2016). Knowledge and adoption of recommended ratoon management practices by the sugarcane growers. Agric. Update, 11(4): 446-448; DOI : 10.15740/HAS/AU/11.4/ 446-448. 